\title{
PHYSICAL PROPERTIES OF A HUMIC CAMBISOL UNDER TILLAGE AND CROPPING SYSTEMS AFTER 12 YEARS $^{(1)}$
}

\author{
Andréia Patrícia Andrade ${ }^{(2)}$, Álvaro Luiz Mafra ${ }^{(3,5)}$, Gizele Rejane \\ Baldo $^{(4)}$, Cristiano Dela Piccolla ${ }^{(4)}$, Ildegardis Bertol ${ }^{(2,5)}$, Jackson \\ Adriano Albuquerque ${ }^{(2,5)}$
}

\begin{abstract}
Soil is the basis underlying the food production chain and it is fundamental to improve and conserve its productive capacity. Imbalanced exploitation can degrade agricultural areas physical, chemical and biologically. The objective of this study was to evaluate some soil physical properties and their relation with organic carbon contents of a Humic Dystrudept under conventional tillage (CT) and no-tillage (NT), for 12 years in rotation (r) and succession (s) cropping systems. The experiment was carried out in Lages, SC (latitude $27^{\circ} 49^{\prime} \mathrm{S}$ and longitude $50^{\circ} 20^{\prime} \mathrm{W}, 937 \mathrm{~m}$ asl), using crop sequences of bean-fallow-maize-fallow-soybean in conventional tillage rotation; maize-fallow in conventional tillage succession; bean-oat-maize-turnip-soybean-vetch in no-tillage rotation; and maize-vetch in notillage succession. The experimental design was completely randomized with four replications. The soil samples were collected in the layers $0-2.5,2.5-5,5-10$, and 10-20 cm. The following properties were analyzed: soil density, porosity, aggregate stability, degree of flocculation, water retention, infiltration, mechanical strength, and total organic carbon. Soil aggregation in the surface layer $(0-5 \mathrm{~cm})$ was better in the no-tillage than the conventional system, related to higher microporosity, organic carbon contents and water retention capacity, indicating that a periodical tillage of this soil is unnecessary. Infiltration was highest in no-tillage with crop succession.
\end{abstract}

Index terms: crop rotation, crop succession, no-tillage, soil management.

\footnotetext{
(1) Parte da Dissertação de Mestrado do primeiro autor no Curso de Manejo do Solo, Programa de Pós-Graduação em Ciências Agrárias, Universidade do Estado de Santa Catarina - UDESC. Recebido para publicação em abril de 2009 e aprovado em outubro de 2009

${ }^{(2)}$ Doutoranda em Manejo do Solo, Universidade do Estado de Santa Catarina - UDESC. Av. Luiz de Camões 2090, CEP 88520000 Lages (SC). E-mail: andreiapatricia74@yahoo.com.br

${ }^{(3)}$ Professor Associado do Departamento de Solos e Recursos Naturais, UDESC, E-mails: a2alm@cav.udesc.br; a2ib@cav.udesc.br; jackson@cav.udesc.br

(4) Acadêmico de Agronomia. UDESC. Bolsista de Iniciação Científica. E-mails: gizelebaldo@yahoo.com.br;cpiccolla@bol.com.br

(5) Bolsista do CNPq.
} 


\title{
RESUMO: ATRIBUTOS FÍSICOS E CARBONO ORGÂNICO DE UM CAMBISSOLO HÚMICO SOB SISTEMAS DE PREPARO E CULTIVO APÓS DOZE ANOS
}

\begin{abstract}
O solo é a base da cadeia produtiva de alimentos, por isso tornam-se necessárias a conservação e manutenção de sua capacidade produtiva. Muitas áreas exploradas de forma incorreta podem apresentar degradação física, química e biológica. O objetivo deste estudo foi avaliar alguns atributos físicos e suas relações com os teores de carbono orgânico de um Cambissolo Húmico alumínico nos sistemas de preparo convencional (PC) e semeadura direta (SD), após 12 anos com rotação (r) e sucessão (s) de culturas. O experimento foi conduzido em Lages - SC, situado a $27^{\circ} 49^{\prime}$ de latitude sul e $50^{\circ} 20^{\prime}$ de longitude oeste, com altitude média de $937 \mathrm{~m}$. As sequências de cultivo foram: feijão-pousio-milho-pousio-soja no preparo convencional rotação; milho-pousio no preparo convencional sucessão; feijão-aveia-milhonabo-soja-ervilhaca na semeadura direta rotação; e milho-ervilhaca na semeadura direta sucessão. O delineamento experimental foi inteiramente casualizado, com quatro repetições. As amostras de solo foram coletadas nas camadas 0-2,5, 2,5-5, 5-10 e 10-20 cm. As variáveis avaliadas foram densidade do solo, porosidade, agregação, grau de floculação, retenção de água, infiltração, resistência mecânica à penetração e teor de carbono orgânico total. A semeadura direta apresentou melhor agregação do solo na camada surface $(0-5 \mathrm{~cm})$ em relação ao preparo convencional, o que está associado à maior microporosidade, teor de carbono orgânico total e retenção de água, não havendo necessidade de revolvimento do solo. A infiltração foi maior na semeadura direta com sucessão de culturas.
\end{abstract}

Termos de indexação: manejo do solo, rotação de culturas, semeadura direta, sucessão de culturas.

\section{INTRODUCTION}

Soil is fundamentally important for human survival on earth, representing the most valuable natural resource of agriculture, which depends on conservation or improvement of the productive characteristics. Soil also fulfills an essential function as a regulator in the water cycle by filtering and retaining it, and is normally conditioned by conservationist management practices that guarantee structural stability and continuous preservation of organic matter (Silva et al., 2005; Cavalieri et al., 2009).

In terms of the physical condition, soil degradation is related to structural modifications that affect water retention capacity, root growth and nutrient availability, reducing crop development and increasing the erosion risk (Bertol et al., 2001). Such modifications are intimately linked to conventional soil preparation, where soils are regularly disturbed, altering soil aggregation, porosity, density, causing accelerated organic matter decomposition, increased soil losses through erosion and, consequently, altering the productive capacity (Llanillo et al., 2006).

Soil density is affected by management systems which alter the structure and, as a result, pore volume and distribution. These alterations affect important physical and hydric properties such as aeration, porosity, plant water availability, and root penetration resistance (Reichert et al., 2003). Alterations in the soil structure due to management practice have frequently resulted in high soil density, making root penetration difficult (Hamza \& Anderson, 2005). Cultural practices, together with soil preparation can affect soil structure, altering density and other related physical aspects (Silva et al., 2008).

Attempts have been made in several studies to describe the effect of management systems on soil physical quality, often related to organic carbon levels (Souza \& Alves, 2003; Tormena et al., 2004). Such alterations can be reflected in hydric aspects, as explained by Abreu et al. (2004), who observed greater infiltration in plots with Crotalaria spectabilis rotation than in plots with continuous no-tillage soybean and chisel-plowed plots in a sandy loam Alfisol. Crop water availability depends on the soil structure, on the distribution of the soil particles and, consequently, on the distribution of different sized pores, together with the quantity of clay and organic matter in the soil (Klein et al., 2006). The beneficial effect of the greater water holding capacity under no-tillage than conventional tillage is evident in hydric-deficient years, in agreement with Karunatilake et al. (2000).

The objective of this study was to evaluate the effect of different preparation systems on soil physical properties and the relationship with organic carbon levels in a long-term experiment (12 years) and to check the need for tilling this shallow clay soil in the no-tillage system. 


\section{MATERIAL AND METHODS}

The experiment was conducted in Lages, state of Santa Catarina, $\left(27^{\circ} 49^{\prime}\right.$ latitude South, $50^{\circ} 20^{\prime}$ longitude West, $937 \mathrm{~m}$ asl). The climate is humid mesothermic, $\mathrm{Cfb}$ type, according to Köppen, with annual mean temperature of maximum $21.7^{\circ} \mathrm{C}$ and minimum $11.5^{\circ} \mathrm{C}$. Mean annual rainfall was $1,674 \mathrm{~mm}$ (Bertol, 1993). The soil is Humic Cambisol (Embrapa, 2006), derived from siltstone and shales, with silt clay texture, containing on average $443 \mathrm{~g} \mathrm{~kg}^{-1}$ clay, $402 \mathrm{~g} \mathrm{~kg}^{-1}$ silt and $155 \mathrm{~g} \mathrm{~kg}^{-1}$ sand in the $0-30 \mathrm{~cm}$ layer (Bertol et al., 2004).

Two soil preparation systems were evaluated; conventional tillage (CT) and no-tillage (NT) and two crop cultivation systems; rotation (r) and succession (s). The experimental design was completely randomized with four replications in plots $(6.5 \mathrm{x}$ $18.0 \mathrm{~m})$. The conventional preparation consisted of one plowing (with a disk plow) and two diskings of the summer crops. During the winter, the conventionally prepared plots remained fallow and the previous crop residues were removed, until 2005; thereafter, the residues of the previous crop, with exception of bean (Phaseolus vulgaris L.), were left in the area. In the no-tillage system, the crops were sown with an appropriate drill, so the soil was disturbed in the sowing line only. The winter NT crops were broadcast before; then, a knife roller was passed to flatten the cover crop, as well as to increase seed contact with the soil and facilitate seedling emergence. The crops were planted as follows: beanfallow-maize (Zea mays L.)-fallow-soybean (Glycine $\max \mathrm{L}$. Merril)-fallow in conventional tillage rotation; maize-fallow in conventional tillage succession; beanoat (Avena sativa L.)-maize-turnip (Raphanus sativus L.)-soybean-vetch (Vicia sativa L.) in no-tillage rotation; and maize-vetch in no-tillage succession. In the winter 2007, a mixture of black oat and vetch was grown on all plots. In the summer, from 2007 onwards, maize was substituted by sorghum in the crop succession.

Soil samples were taken in February 2008, during flowering of the summer crops. Two sub-samples were taken in each plot, at depths of $0-2.5,2.5-5,5-10$, and 10-20 cm, for physical and carbon analyses.

Soil density was determined in undisturbed samples collected with a steel ring (Kiehl, 1979). Particle density was determined by the volumetric flask method (Embrapa, 1997). Soil microporosity was measured on the sand tension table with suction of $60 \mathrm{~cm}$, and total porosity (TP) was calculated based on the relationship between soil and particle density. Macroporosity was calculated as the difference between TP and microporosity (Embrapa, 1997). Density, total porosity, microporosity, and macroporosity were determined from the same undisturbed sample. Total clay was obtained after agitation and dispersion in $1 \mathrm{~mol} \mathrm{~L}^{-1} \mathrm{Na} \mathrm{OH}$ and natural clay after dispersion in water, by the densimeter method (Bouyoucos, 1962). After determining the granulometric fractions, the degree of flocculation was calculated. Soil aggregate stability was determined from disturbed samples by wet filtering, according to the methodology of Kemper $\&$ Chepil (1965), represented by the mean weighted diameter (MWD).

To determine total organic carbon, the samples were collected with a soil core sampler at random points but at the same depths and in the same areas as for the physical analysis. Organic carbon was determined by titulometry after oxidation in an acidic medium with potassium dichromate (Tedesco et al., 1995).

The soil water infiltration rate was evaluated using concentric cylinders with a variable hydraulic charge, by the method described by Forsythe (1975), at one point in the central area of each plot, near the sampling points for physical analysis and organic carbon, representing one experimental unit. The water infiltration data was adjusted by the equation: $\mathrm{i}=\mathrm{y}_{0}$ $+a^{b . t}$, where $i=$ estimated rate of water infiltration in the soil $\left(\mathrm{cm} \mathrm{h}^{-1}\right) ; \mathrm{t}=$ time $(\mathrm{h}) ; \mathrm{y}_{0}, \mathrm{a}$ and $\mathrm{b}=$ adjustment parameters. Soil resistance was determined using a "Falker penetrolog" penetrometer to a depth of $20 \mathrm{~cm}$, with readings at every $10 \mathrm{~mm}$, and 10 readings per plot at random points, different from the sampling points for the other variables. At the point of determination, the gravimetric water content was measured. The water retention curves were obtained from the undisturbed samples and determined based on the volumetric water content using a sand tension table for potentials of 1, 6 and $10 \mathrm{kPa}$ and on Richards' apparatus, with porous plates, for potentials of 30 and $100 \mathrm{kPa}$.

The results were subjected to variance analysis by the $\mathrm{F}$ test and by comparison of means by the $\mathrm{t}$ test considering treatment, depth and interaction between these factors, in the completely randomized model (Gomes \& Garcia, 2002), using the program SAS (SAS, 2002). For soil density, total porosity, MWD, degree of flocculation, macroporosity, microporosity, organic carbon, and water content, the mean of the two sub-samples collected in each plot represented a replication. For the variable penetration resistance, each replication consisted of the mean of 10 observations per plot. The relationship between the different attributes was evaluated by Pearson's correlation.

\section{RESULTS AND DISCUSSION}

Soil density varied from 1.13 to $1.38 \mathrm{~g} \mathrm{~cm}^{-3}$ (Figure 1a) increasing with depth in all treatments. Density was lower in the $0-2.5 \mathrm{~cm}$ and $10-20 \mathrm{~cm}$ layers of the NTs (no-tillage succession) than the other treatments, but not in the $5-10 \mathrm{~cm}$ layer. This behavior accompanied a reduction in soil porosity with 
increasing depth; a total porosity was greater in the top layer in NTs than the other treatments (Figure 1b). These results differ from those of Bertol et al. (2001) on the same soil and in the same experimental area, which showed greater soil density in the NT system, especially in the top layer, made no comparison with other cultivation systems. The lower density in NTs compared to CT could be related to the increase in organic carbon levels in the top layer (Figure 2), which normally reduces soil density, possibly due to the effect of organic constituents on the soil structure and aggregation (Silva et al., 2006).

Total porosity varied between 0.45 and $0.55 \mathrm{~m}^{3} \mathrm{~m}^{-3}$ (Figure 1b), and was greater in the surface layer of NTs than the other treatments. In the 2.5-5 cm layer total porosity in NTr was lower than in the other treatments, which did not differ from each other and, in the deepest layer, porosity in NTs was greater than in the other treatments. Macroporosity varied between 0.05 and $0.15 \mathrm{~m}^{3} \mathrm{~m}^{-3}$, and was lower in the NTr than the other treatments in the surface layer. At 2.5-5 cm, macroporosity was greater under CT than NT (Figure 1c). In the cultivation systems, macroporosity in NT in crop succession was greater than in rotation at all soil depths evaluated, except for the 5-10 cm layer. Reynolds et al. (2002) considered a value of $0.10 \mathrm{~m}^{3} \mathrm{~m}^{-3}$ as the minimum volume of macropores to guarantee a sufficient aeration of the root system. The values observed in NTr were below this limit, thus representing physical restriction to plant growth.
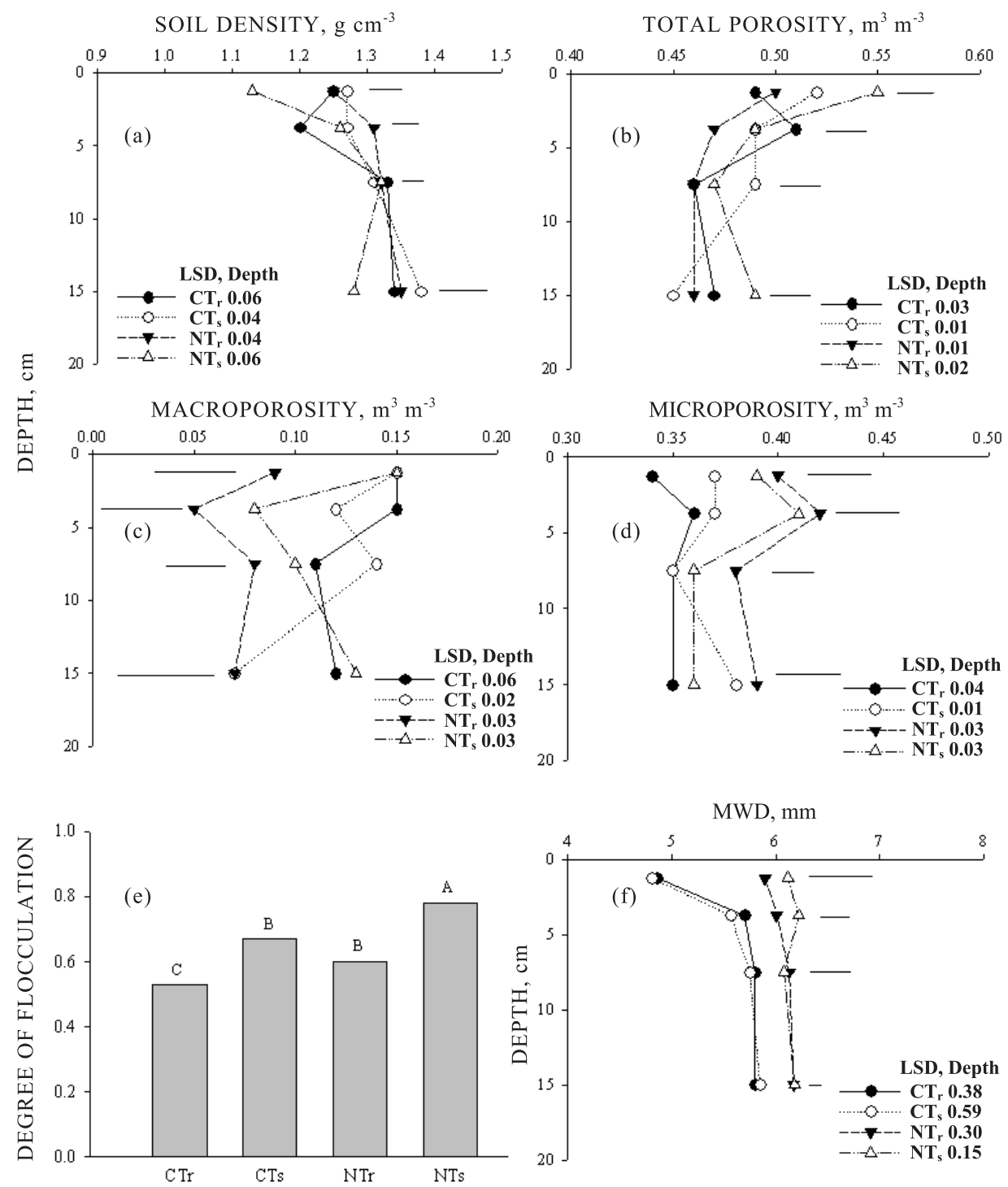

Figure 1. Soil density (a), total porosity (b), macroporosity (c), microporosity (d), degree of flocculation (e) and mean weighted diameter of aggregates (f) under conventional tillage (CT) and no-tillage (NT) and in cultivation systems with rotation (r) and succession (s) of crops, on a Humic Cambisol, Lages, 2008. Horizontal bars indicate least significant differences between treatments at the same depth, based on the $t$ test; letters indicate differences between mean layers by the $t$ test $(p<0.05) . n=64$ observations. 
Microporosity was greater in areas under NT than under CT (Figure 1d), and also greater in CTs compared to CTn, in the deepest layer evaluated. In NT, the cultivation systems differed only in the 10 $20 \mathrm{~cm}$ layer, where microporosity in NTr was greater than in NTs.

The degree of clay flocculation reached a mean of 0.78 across all layers in NTs and showed difference to CTs (Figure 1e). The greater degree of clay flocculation in this treatment can be associated with the higher level of organic carbon observed in NTs (Figure 2).

The mean weighted diameter (MWD) was greater in NT than CT in the 0-5 cm layer, (5.9- $6.2 \mathrm{~mm}$ in $\mathrm{NT}$, and 4.8 - $5.8 \mathrm{~mm}$ in CT) (Figure 1f), which is in agreement with results of Bertol et al. (2000) also for a Humic Cambisol in Santa Catarina, and of Silva et al. (2006), for a loamy Acrisol in Rio Grande do Sul. These results suggest that there is a high degree of aggregate stability and soil resistance to hydric erosion under no tillage systems. In the current study, there were no differences between the cultivation systems in both soil preparation systems with regard to aggregate stability, which increased with depth in $\mathrm{CTr}$ and in NTr. Lima et al. (2008) also observed an increase in MWD with increasing depth when analysing NT and CT systems on a Haplic Planosol in Capão do Leão, RS.

These results indicate that the no-tillage system maintains a better soil structure while conventional tillage can reduce aggregation in the surface layer. This must be due to the periodic mechanical disturbance of the soil under conventional preparation and also to the lower level of organic carbon in this management system, since organic matter is a bonding agent between soil particles, facilitating

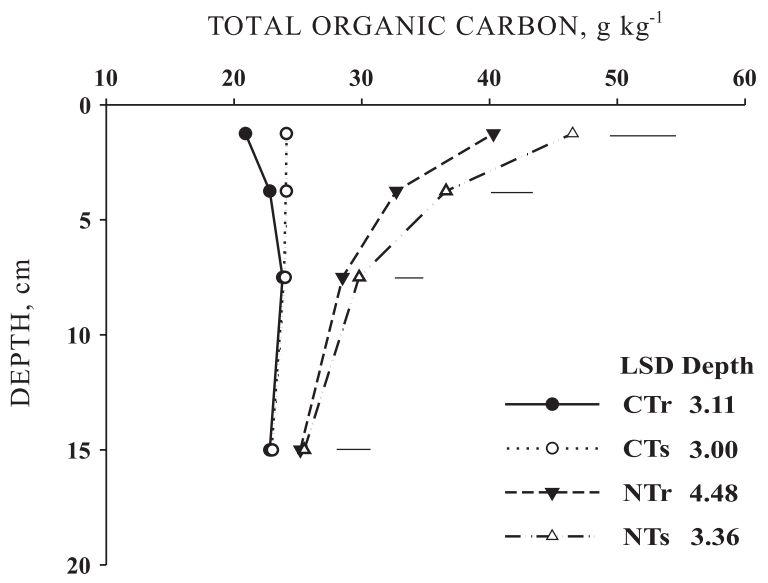

Figure 2. Total organic carbon in conventional tillage (CT) and no-tillage (NT) systems and in rotation (r) and succession (s) crop systems, on a Humic Cambisol, Lages, 2008. Horizontal bars indicate least significant differences between treatments at the same depth, based on the test $(p<0.05)$. $\mathrm{n}=64$ observations. aggregation and physical structuring (Bertol et al., 2000).

Soil penetration resistance evaluated with a penetrometer varied between $134-1,546 \mathrm{kPa}$ (Figure 3a). Soil resistance increased with depth in all treatments, reaching highest values in the $5-10 \mathrm{~cm}$ layer in NTr. According to Benghough \& Mullins (1990) resistance of $>2000 \mathrm{kPa}$ is considered critical to root development. Therefore, the soil preparation and cultivation systems studied did not modify soil penetration resistance to a point that affected plant development. Resistance was positively correlated to the MWD $(r=0.37$ and $p<0.05)$. The variations in resistance were parallel to moisture changes in depth. At the time of resistance evaluation, moisture was greater in NT than CT (Figure 3b).

Many authors have used soil penetration resistance to evaluate the effects of different soil management systems on the root environment. Cunha et al. (2002) found a strong relationship between soil penetration resistance and moisure and density levels, where the increment in soil density and reduction in the amount of water increased soil penetration resistance. It is therefore recommendable to determine soil penetration resistance when the soil is near field capacity (Henderson, 1989), due to the good correlation between soil density, penetration resistance and root growth under this condition.

Under field capacity conditions, at a tension of $10 \mathrm{kPa}$, the mean volumetric water content in the layers evaluated was $0.33-0.35 \mathrm{~m}^{3} \mathrm{~m}^{-3}$ in conventional tillage and $0.37-0.38 \mathrm{~m}^{3} \mathrm{~m}^{-3}$ in no-tillage (Table 1). At a tension of $1 \mathrm{kPa}$, water retention under conventional tillage with rotation (CTr) was lower than in the other treatments, and at the other tensions water retention was higher under NT than CT, without any difference between the cultivation systems. In this last treatment, microporosity was also greater (Figure 1d) than under CT, demonstrating the importance of micropores for water retention. Albuquerque et al. (2001) evaluated the physical properties of a Red Nitosol in Lages, SC, and noted that no-tillage favoured greater water storage in the soil compared to conventional tillage, which was associated with a greater quantity of micropores.

Water infiltration was greatest under no-tillage crop succession (Figure 4). The greater water infiltration under NTs agrees with the values of greater total porosity and lower soil density in this treatment (Figure 1a and 1b), mainly in the $0-2.5 \mathrm{~cm}$ layer. These conditions favor water infiltration into the soil, due to the greater pore space available. In NTs, the soil was not tilled and the succession with maize and vetch could allow more constant root exploration during the cultivation periods. No-tillage could therefore contribute to the recovery of soil physical properties in the surface layer, which is often favoured by the presence of cover crops or the residual effect of crops used in rotation systems (Alves \& 

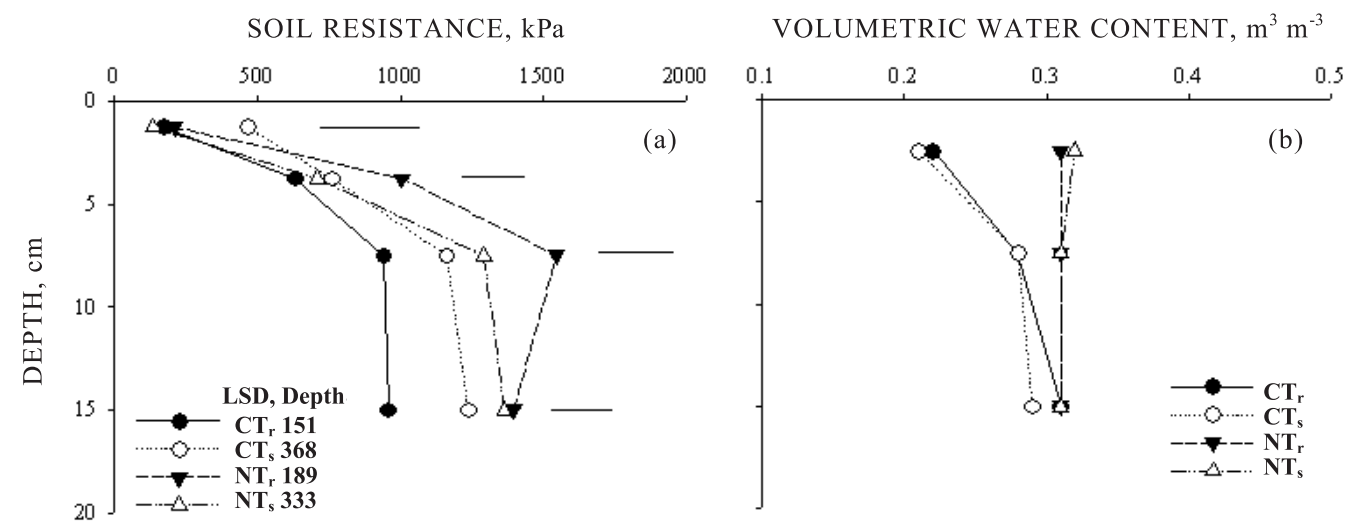

Figure 3. Soil penetration resistance (a) and volumetric water content at the time of soil penetration resistances evaluation (b) under conventional tillage (CT) and no-tillage (NT) and rotation (r) and succession (s) crop cultivation systems in Humic Cambisol, Lages, 2008. Horizontal bars indicate least significant differences between treatments at the same depth, based on the test. Means of four replications. $n=64$. CV soil resistance $=20 \%$.

Table 1. Mean soil volumetric moisture values $\left(\mathrm{m}^{3} \mathrm{~m}^{-3}\right)$ for matric potentials of $1,6,10,30$, and $100 \mathrm{kPa}$, in the 0-20 cm layer, under conventional tillage (CT) and no-tillage (NT) and crop rotation (r) and succession (s) systems, on a Humic Cambisol, Lages, 2008, $\mathrm{n}=64$ observations

\begin{tabular}{|c|c|c|c|c|c|c|}
\hline Treatment & $1 \mathrm{kPa}$ & $6 \mathrm{kPa}$ & $10 \mathrm{kPa}$ & $30 \mathrm{kPa}$ & $100 \mathrm{kPa}$ & $\mathrm{CV}$ \\
\hline & \multicolumn{5}{|c|}{ Volumetric water content, $\mathrm{m}^{3} \mathrm{~m}^{-3}$} & $\%$ \\
\hline $\mathrm{CTr}$ & $0.40 \mathrm{~b}$ & $0.35 \mathrm{c}$ & $0.33 \mathrm{c}$ & $0.31 \mathrm{c}$ & $0.30 \mathrm{c}$ & 9 \\
\hline $\mathrm{CTs}$ & $0.42 \mathrm{a}$ & $0.36 \mathrm{~b}$ & $0.35 \mathrm{~b}$ & $0.33 \mathrm{~b}$ & $0.31 \mathrm{~b}$ & 6 \\
\hline $\mathrm{NTr}$ & $0.43 \mathrm{a}$ & $0.39 \mathrm{a}$ & $0.38 \mathrm{a}$ & $0.36 \mathrm{a}$ & $0.35 \mathrm{a}$ & 9 \\
\hline NTs & $0.43 \mathrm{a}$ & $0.38 \mathrm{a}$ & $0.37 \mathrm{a}$ & $0.35 \mathrm{a}$ & $0.35 \mathrm{a}$ & 9 \\
\hline
\end{tabular}

The same letters in the columns indicate similarities between means by the test $(p<0.05)$.

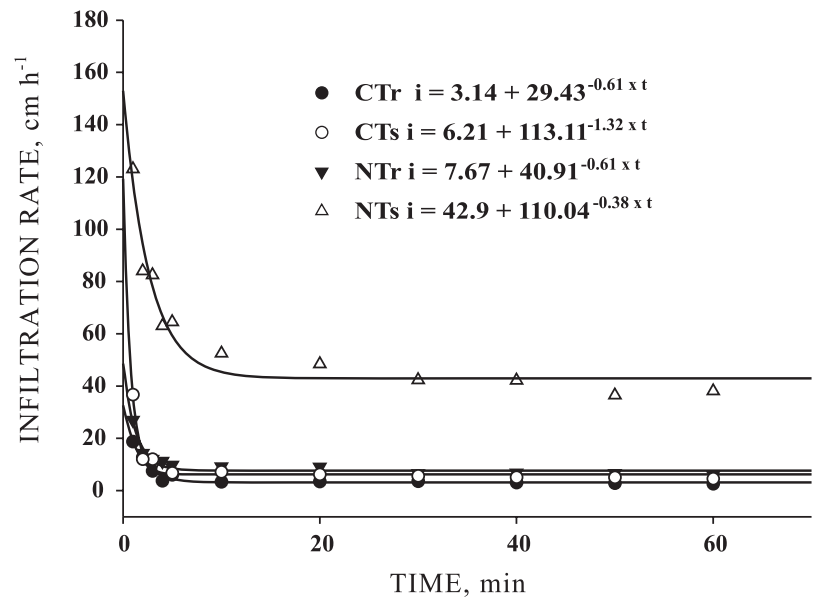

Figure 4. Water infiltration under conventional tillage (CT) and no-tillage (NT) with rotation (r) and succession (s) crop systems, in a Humic Cambisol, Lages, 2008. Means of four replications; $\mathrm{n}=64$ observations.

Suzuki, 2004). The combined effect of crop residues on the soil surface with a continuous and deep network of macropores could increase soil hydraulic conductivity under no-tillage (Cavalieri et al., 2009).

\section{CONCLUSIONS}

1. The soil physical properties in no-tillage systems remain adequate for plant development and, compared to the conventional system, microporosity, aggregate stability, and water retention are increased.

2. Penetration resistance was greater in the notillage system, but the measured value was not considered critical to plant root development at the moisture contents of this study.

3. In the surface soil layer of the no-tillage crop succession, soil density values were reduced and total porosity and water infiltration increased.

4. Particularly near the soil surface, soil structure conditions under no-tillage are better and organic carbon contents higher than in the conventional system. 


\section{LITERATURE CITED}

ABREU, S.L.; REICHERT, J.M. \& REINERT, D.J. Escarificação mecânica e biológica para a redução da compactação em argissolo franco arenoso em plantio direto. R. Bras. Ci. Solo, 28:519-531, 2004.

ALBUQUERQUE, J.A.; SANGOI, L. \& ENDER, M. Efeitos da integração lavoura-pecuária nas propriedades físicas do solo e características da cultura do milho. R. Bras. Ci. Solo, 25:717-723, 2001.

ALVES, M.C. \& SUZUKI, L.E.A.S. Influência de diferentes sistemas de manejo do solo na recuperação de suas propriedades físicas. Acta Sci. Agron., 26:27-34, 2004.

BENGHOUGH, A.G. \& MULLINS, C.E. Mechanical impedance to root growth: A review of experimental techniques and root growth responses. J. Soil Sci., 41:341-358, 1990.

BERTOL, I. Índice de erosividade $\left(\mathrm{EI}_{30}\right)$ para Lages $(\mathrm{SC})-1^{\mathrm{a}}$ aproximação. Pesq. Agropec. Bras., 28:515-521, 1993.

BERTOL, I.; ALBUQUERQUE, J.A.; LEITE, D.; AMARAL, A.J. \& ZOLDAN JUNIOR, W.A. Propriedades físicas do solo sob preparo convencional e semeadura direta em rotação e sucessão de culturas, comparadas às do campo nativo. R. Bras. Ci. Solo, 28:155-163, 2004.

BERTOL, I.; BEUTLER, J.F.; LEITE, D. \& BATISTELA, O. Propriedades físicas de um Cambissolo Húmico afetadas pelo tipo de manejo do solo. Sci. Agric., 58:555-560, 2001.

BERTOL, I.; SCHICK, J.; MASSARIOL, J.M.; REIS, E.F. \& DILY, L. Propriedades físicas de um Cambissolo Húmico álico afetadas pelo manejo do solo. Ci. Rural, 30:91-95, 2000 .

BOUYOUCOS, G.J. Hydrometer method improved for making particle size analyses of soils. Agron. J., 54:464-465, 1962.

CAVALIERI, K.M.V.; SILVA, A.P.; TORMENA, C.A.; LEÃO, T.P.; DEXTER, A.R. \& HAKANSSON, I. Long-term effects of no-tillage on dynamic soil physical properties in a Rhodic Ferrasol in Paraná, Brazil. Soil Till. Res., 103:158. 164, 2009.

CUNHA, J.P.A.R.; VIEIRA, L.B. \& MAGALHÃES, A.C. Resistência mecânica do solo à penetração sob diferentes densidades e teores de água. Eng. Agríc., 10:1-4, 2002.

EMPRESA BRASILEIRA DE PESQUISA AGROPECUÁRIA EMBRAPA. Centro Nacional de Pesquisa de Solos. Manual de métodos de análise de solo. 2.ed. Rio de Janeiro, 1997. $212 \mathrm{p}$

EMPRESA BRASILEIRA DE PESQUISA AGROPECUÁRIA EMBRAPA. Centro Nacional de Pesquisa de Solos. Sistema brasileiro de classificação de solos. 2.ed. Rio de Janeiro, 2006. 306p.

FORSYTHE, W. Física de suelos: Manual de laboratório. San José, Internacional de Ciências Agrícolas, 1975. 212p.

GOMES, F.P. \& GARCIA, H.G. Estatística aplicada a experimentos agronômicos e florestais: Exposição com exemplos e orientações para uso de aplicativos. Piracicaba, FEALQ, 2002. 309p.
HAMZA, M.A. \& ANDERSON, W.K. Soil compaction in cropping systems: A review of the nature, causes and possible solutions. Soil Till. Res., 82:121-145, 2005.

HENDERSON, C.W.L. Using a penetrometer to predict the effects of soil compaction on the growth and yield of wheat, sandy soils. Austr. J. Agric Res, 40:497-508, 1989.

KARUNATILAKE, U.; van ES, H.M. \& SCHINDELBECK, R.R. Soil and maize response to plow and no-tillage after alfafato-maize conversion on a clay loam soil in New York. Soil Till. Res., 55:31-42, 2000.

KEMPER, W.D. \& CHEPIL, W.S. Size distribution of aggregation. In: BLACK, C.A. ed. Methods of soil analysis. Madison, American Society Agronomy, 1965. p. 499-510. (Agronomy Monoghaph, 9)

KIEHL, E.J. Manual de edafologia. Relações solo-planta. São Paulo, Ceres, 1979. 264p.

KLEIN, V.A.; REICHERT, J.M. \& REINERT, D.J. Água disponível em um Latossolo Vermelho argiloso e murcha fisiológica de culturas. R. Bras. Eng. Agric. Amb., 10:646650, 2006.

LLANILLO, R.F.; RICHART, A.; TAVERES FILHO, J.; GUIMARÃES, M.F. \& FERREIRA, R.R.M. Evolução de propriedades físicas do solo em função dos sistemas de manejo em culturas anuais. Semina: Ci. Agr., 27:205$220,2006$.

LIMA, C.L.R.; PILLON, C.N.; SUZUKI, L.E.A.S. \& CRUZ, L.E.C. Atributos físicos de um Planossolo Háplico sob sistemas de manejo comparados aos do campo nativo. R. Bras. Ci. Solo, 32:1849-1855, 2008.

REICHERT, J.M.; REINERT, D.J. \& BRAIDA, J.A. Qualidade dos solos e sustentabilidade de sistemas agrícola. Ci. Amb., 27:29-48, 2003.

REYNOLDS, W.D.; BOWMAN, B.T.; DRURY, C.F.; TAN, C.S. $\&$ LU, X. Indicators of good soil physical quality: Density and storage parameters. Geoderma, 110:131-146, 2002.

SAS Learning Edition. Getting started with the SAS learning edition. Cary, 2002. 200p.

SILVA, M.A.S.; MAFRA, A.L.; ALBUQUERQUE, J.A.; BAYER, C. \& MIELNICZUK, J. Atributos físicos do solo relacionados ao armazenamento de água em um Argissolo Vermelho sob diferentes sistemas de preparo. Ci. Rural, 35:544-552, 2005.

SILVA, M.A.S.; MAFRA, A.L.; ALBUQUERQUE, J.A.; ROSA, J.D.; BAYER, C. \& MIELNICZUK, J. Propriedades físicas e teor de carbono orgânico de um Argissolo Vermelho sob distintos sistemas de uso e manejo. R. Bras. Ci. Solo, 30:329-337, 2006.

SILVA, M. G.; ARF, O.; ALVES, M. C. \& BUZETTI, S. Sucessão de culturas e sua influência nas propriedades físicas do solo e na produtividade do feijoeiro de inverno irrigado, em diferentes sistemas de manejo do solo. Bragantia, 67:335-347, 2008.

SOUZA, Z.M. \& ALVES, M.C. Propriedades físicas e teor de matéria orgânica em um Latossolo Vermelho de cerrado sob diferentes usos e manejos. Acta Sci. Agron., 25:27-34, 2003. 
TEDESCO, M.J.; GIANELLO, C.; BISSANI, C.A.; BOHNEN, H. \& VOLKWEISS, S.J. Análises de solo, plantas e outros materiais. 2.ed. Porto Alegre, Universidade Federal do Rio Grande do Sul, 1995. 174p.
TORMENA, C.A.; FRIEDRICH, R.; PINTRO, J.C.; COSTA, A.C.S. \& FIDALSKI, J. Propriedades físicas e taxa de estratificação de carbono orgânico num Latossolo Vermelho após dez anos sob dois sistemas de manejo. R. Bras. Ci. Solo, 28:1023-1031, 2004. 